Khodachuk Yana, Maslova Yuliia. Information and communication management in university (on the example of the National University of Ostroh Academy and Silesian University in Katowice). Pedagogy and Psychology of Sport. 2020;6(2):85-94. elSSN 2450-6605. DOI http://dx.doi.org/10.12775/PPS.2020.06.02.008

https://apcz.umk.pl/czasopisma/index.php/PPS/article/view/PPS.2020.06.02.008 https://zenodo.org/record/3816952

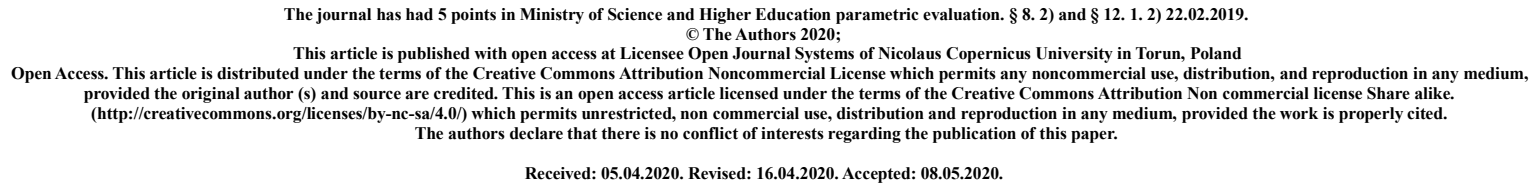

\title{
Information and communication management in university (on the example of the National University of Ostroh Academy and Silesian University in Katowice)
}

\author{
Khodachuk Yana, Maslova Yuliia \\ Ходачук Яна, Маслова Юлія
}

\section{National University of Ostroh Academy, Ostroh, Ukraine}

\section{Annotation}

The article deals with theoretical issues of information and communication management of the university. The role and impact of information and communication management on universities have been analyzed and researched on the example of Ostroh National University and Silesian University in Katowice. They are comparing the results obtained and making recommendations for improving the information and communication sphere in the universities.

Key words: information; communication; university; management; information and communication management. 
УДК 005.5

Інформаційно-комунікаційний менеджмент університету (на прикладі Національного університету «Острозька академія» та Сілезького університету в Катовіце)

\author{
Ходачук Яна, Маслова Юлія
}

У статті розглянуто теоретичні питання інформаційно-комунікаційного менеджменту університету. Проаналізовано та досліджено на прикладі Національного університету «Острозька академія» та Сілезького університету в Катовіце роль та вплив інформаційно-комунікаційного менеджменту. Здійснення порівняння отриманих результатів та створення рекомендацій для покращення інформаційнокомунікаційної сфери у даних університетах.

Ключові слова: інформація; комунікація; університет; менеджмент; управління; інформаційнокомунікаційний менеджмент.

Постановка проблеми. У наш час зі всіх сфер суспільства, найстрімкішого розвитку зазнала сфера менеджменту. 3 кожним днем попит на інформаційно-комунікаційного менеджменту продовжує динамічно рости. Швидкий розвиток Інтернет-мережі, створення нових платформ для обміну та поширення інформації,виступили прекраснимикаталізаторами для модернізації насамперед інформаційної та комунікаційної сфери закладів вищої освіти.

Функціонування університету безпосередньо залежить від налагодженої системи менеджменту, а саме: створення, пошуку, збирання, обробки, аналізу та поширення інформації. Адже дана система впливає як на робочий процес, так і на навчальний.У цій статті проведено аналіз та порівняння інформаційно-комунікаційного менеджменту на прикладі Національного університету «Острозька академія»та Сілезького університету в Катовіце.

Аналіз останніх досліджень і публікацій.До науковців, які займалися дослідженням та вивченням вищевказаноїтеми можна віднести, як Бебик В., Віценовський К., Воронкова В., Романчук В., Хергет Й., Czekaj J., Martyniak Z., Malara Z., Rzęchowski J. Для цих дослідників характерним $\epsilon$ власне розуміння поняття змісту, методів та функційінформаційно-комунікаційного менеджменту в умовах зростання нових технологій.

\title{
Завданнями даної статті є:
}

- Визначити поняття інформаційно-комунікаційного менеджменту.

- Проаналізувати методи та процеси поширення інформації у Національного університету «Острозька академія». 
- Проаналізувати методи та процеси поширення інформації у Сілезькому університеті.

- $\quad$ Порівняти отримані дані двох університетів та зробити висновки.

Метою статті є на прикладі Національного університету «Острозька академія» та Сілезького університету в Катовіце продемонструвати роботу інформаційнокомунікаційного менеджменту.

Викладення основного матеріалу дослідження.Сучасний університет - це складний комплекс, що передбачає збереження традицій та введення інновацій у освітній процес, наукових досліджень, поєднання навчальних та дослідницько-розважальних завдань, а також вирішення соціальних питань [7]. Для якісногофункціонування усіх процесів у вищих навчальних закладах використовують менеджмент.Одним із його підвидів $\epsilon$ інформаційно-комунікаційний менеджмент. Це система управління інформаційнокомунікаційною сферою суспільства на основі використання методів, форм і технологій правового, соціального, економічного,гуманітарногоі політичного менеджменту i маркетингу[1]. Метою є оптимальне підтримання усіх ділових процесів та стратегій і підтримання конкурентоспроможності. Й. Хергет вважає, що суть інформаційнокомунікаційного менеджменту полягає у вирішенні трьох задач:

1. Формування (побудова інформаційних систем - людина, інформаційні ресурси та інформаційно-комунікаційні технології).

2. Керування (управління усіма інформаційними процесами).

3. Розвиток (адаптація інформаційних систем до оточуючого середовища) [8].

Основним завданням інформаційно-комунікаційного менеджменту $є$ інформаційне забезпечення усіх видів і форм менеджменту, адже основний ресурс менеджменту - це інформація, а його технологією є комунікація.Комунікація та інформування займає важливе місце серед закладів вищої освіти, оскільки завдяки цим процесам передається важлива інформація як для студентів та абітурієнтів, так і для працівників закладу та викладачів. Комунікація є однією з двох сполучних функцій менеджменту і допомагає вирішувати управлінські проблеми. Проблеми можуть створюватися не тільки 3 середини університету, але й ззовні. Тому інформація розподіляється на внутрішню (яка формується в межах університету) та зовнішню (формується поза межами університету).

Інформація як фактор, що підтримує процес управління, стає важливим капіталом і головним рушієм в управлінні підприємством[9]. Вона відіграє важливу роль при створенні іміджу університету. Бо саме остання займає домінуючу позицію у формуванні напрямів діяльності освітнього закладу. Вона аналізує цільові аудиторії (абітурієнтів та їхніх батьків, інших закладів вищої освіти, студентів інших університетів тощо) у ставленні до освітніх послуг, особливості яких обумовлюють виконання закладом освіти функції гаранта та очікуваної якості послуг.Задля підвищення рівня довіри до цього університету [3].

Налагодження ефективної внутрішньої комунікації є головним елементом посилення спроможності університету. Не слід забувати і про культуру організації , оскільки вона 
надає освітньому закладу стратегічну перевагу. Тому те, з чого складається культура цілі, цінності, практики - повинні ефективно доноситись до професорськовикладацького складу та студентів [2]. До внутрішньої комунікації відносять, у першу чергу, спілкування із працівниками та студентами. Ця комунікація може бути оптимізованою за допомогою різноманітних інструментів, а саме: інтрамережі, збори університету, ректорат тощо.Разом з цим процеси внутрішньої комунікації повинні відстежуватися, із перспективою їх подальшого аналізу і зробити висновок про стан університету з точки зору збереження ефективного функціонування, цілісності та взаєморозуміння між його ланками. Важливу роль тут відіграють інформаційні потоки. Як стверджує Матвієнко О. В. «Інформаційний потік - це сукупність повідомлень, які циркулюють у системі, і необхідні для здійснення процесів управління»[6]. Потоки повинні бути побудовані логічно та чітко . Розглянемо це на прикладі інформування ректоразакладу вищої освіти. Він кожного дня отримуєвелику кількість інформації, яку потрібно опрацьовувати. Тому шляхом автоматичного відсіювання інформації ректор забезпечує свою максимальну працездатність. Такий ж механізм повинен застосовуватися для студентства. Вцей же час студенти самі повинні навчитися контролювати свої інформаційні потоки, а також навчитися створювати логічні інформаційні повідомлення. Існує декілька видів інформаційних повідомлень:

- $\quad$ Мовні повідомлення відбуваються внаслідок вербального спілкування 3 використанням мовних знакових одиниць, а також невербальних засобів.

- Паперові повідомленні передаються за допомогою паперових носіїв. До прикладу, накази, оголошення, розпорядження тощо.

- $\quad$ Електронні повідомлення - це інформація, яка надається через мережу і може бути відтворена чи зображена у електронному вигляді. Наприклад, розклад, е-таil від деканату, повідомлення у соціальній мережі від викладача, оголошення на сайті університету.

- $\mathrm{TV}$-повідомлення - цеінформація, якатранслюється за допомогою телебачення. Найчастіше до них відносять передвиборчі ролики політиків та звернення до українського народу[6].

Інформація завжди циркулює у організації не дивлячись ні на що, але існують інформаційні бар'єри, які можуть стати причиною пошкодження чи ненадходження повідомлення. До цих бар'єрів відносять:

1. Викривлення повідомлення - це викривлення, які зроблені цілком ненавмисно в ході міжособистісної комунікації або при помилковому опрацюванні інформації. Існують також і навмисні викривлення. Під час цих викривлень носій не погоджується 3 інформацією і змінює іï у власних інтересах. Такі дії можуть спровокувати непорозуміння та конфлікти як у професорсько-викладацькому колективі, так і в студентському.

2. Інформаційні перенавантаження відбуваються тоді, коли студент зайнятий опрацюванням інформації, що надходить і йому потрібно підтримувати інформаційний обмін, але він не в змозі ефективно реагувати на всю інформацію, тому відсіює ту, яка $є$ менш важливою на його думку. Хоча ця оцінка може бути хибною. 
3. Незадовільна структура організації. При передачі інформації з одного рівня управління на інший, в результаті фільтрації втрачається третина обсягу інформації. Тому найкращим вирішенням даної проблеми $є$ передавання інформації напряму. До прикладу, зустріч студентів з ректором, або ж зустріч студентів з деканом [4].

Отож, інформація та комунікація займає важливе місце в управлінській системі закладів вищої освіти. Завдяки інформаційному менеджменту відбувається процеси, які допомагають налагодити роботу вищого навчального закладу, створюють робочу атмосферу та сприяють зміцненню репутації. Тепер на конкретних прикладах Національного університету «Острозька академія» та Сілезького університету розглянемо та порівняємо систему менеджменту.

Національний університет «Острозька академія» є одним із найстаріших закладів вищої освіти в Україні. Він славиться своєю репутацією, рівнем освіти та високим рівнем кваліфікації викладачів. Його ще називають українським Оксфордом. Звісно ж важливу роль у цьому відіграло правильне позиціонування та чітка управлінська діяльність. Потрібно пам'ятати, що завдяки професійному використанню інформаційнокомунікаційного менеджменту в Національному університеті «Острозька академія» існує така чітка та налагоджена система управління.

Перш за все, головні функції відіграють комунікація та інформація. Завдяки ним відбувається налагоджена робота всього університету. На даному рисунку зображено схему інформаційних процесів у Національному університеті «Острозька академія» [5].

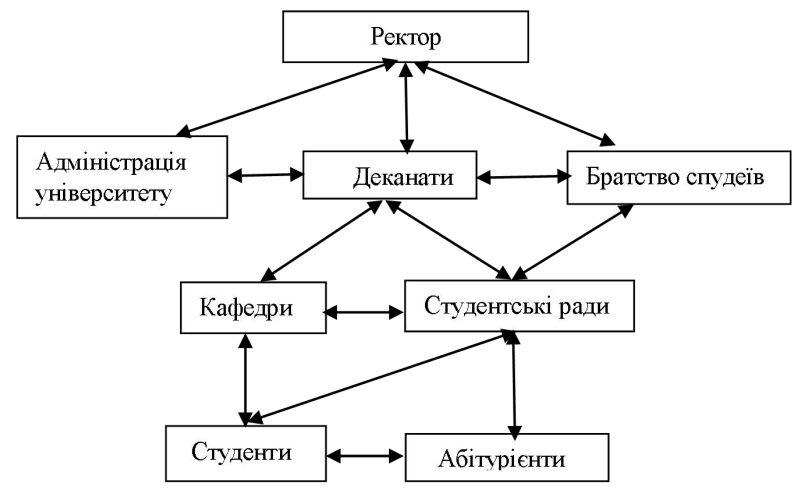

Рис. 1. Передача інформації у Національному університеті «Острозька академія»

Посилаючись на цю схему, можна зробити висновок, що інформування та комунікація у Національному університеті «Острозька академія» мають відкритий характер. Студенти без проблем можуть звернутися до викладачів кафедр, деканів чи навіть ректора i навпаки. Завдяки цим факторам студенти відчувають себе захищеними і у своєму середовищі, оскільки їм завжди готові прийти на допомогу. 
Потрібно звертати увагу і на те, якими способами відбувається інформування та комунікація між професорсько-викладацьким складом та студентами університету. Чим більше заходів, де можна на пряму комунікувати та отримувати важливу інформацію, тим краще. Національний університет «Острозька академія» у своїй діяльності використовує такі способи:

- Ректорат -це засідання під час якого збираються: ректор, керівники університетських відділів, декани (або ж заступники), голова Братства спудеївта представники студентських рад. Під час ректоратів обговорюють важливу інформацію та вирішують складні питання, які виникають під час робочого процесу, а по завершенню ректоратів інформація передається усім викладачам та студентам.

- $\quad$ Зустріч із ректором - можливість студентства поспілкуватись із ректором на пріоритетні теми, а також отримати необхідну інформацію від першоджерела.

- $\quad$ Зустріч факультету - можливість декана, заступника декана та студентського декана поширити інформацію поміж студентів наживо. У свою ж чергу студенти мають можливість поставити питання, які їх турбують у межах свого студентського життя чи навчального процесу.

- $\quad$ Старостат - можливість для декана, заступника декана, студентського декана чи студента поширити інформацію для старост груп, які у свою чергу передадуть інформацію групі.

- Година куратора - це зустріч із куратором групи під час якої викладач обмінюється інформацією зі студентами. Інформація може бути присвячена останнім новинам в університеті, зміні навчальних планів або ж тематизована.

- Друковані носії - найоптимальніший спосіб поширення інформації, але трішки застарілий у XXI столітті, оскільки більшість студентів проводить свій час в Інтернеті (постери, афіші, листівки, буклети, подяки, розклади які знаходяться на інформаційних стендах факультетів).

- Соціальні мережі - Інтернет-простір, де можна висвітлити усі події, що відбуватимуться в університеті. Національний університет «Острозька академія» позиціонує себе як прогресивний заклад вищої освіти, тому поширює інформацію завдяки соціальним мережам. У Instagram є офіційна сторінка університету, офіційні сторінки факультетів та наукових клубів. Вони діляться важливою інформацією зі студентами i водночасстуденти можуть комунікувати 3 авторами постів та представниками студентства у коментарях. Ще профіль університету та факультетів можна знайти у Telegram, Facebook, Youtube. Першоджерелом в Інтернет-просторі можна вважати офіційний сайт університету.

- $\quad$ Електронні носії - $\epsilon$ сучасним видом передачі інформації для студентів. На території та в середині Національного університету «Острозька академія» розташовані телевізори завдяки яким часто поширюють важливу інформацію для студентів. До прикладу, коли ти йдеш на пару в головний корпус університету, над вхідними дверима висить монітор, який висвітлює останні події, що відбуваються в університеті. У новому корпусі університету $\epsilon$ настінні сенсорні телеекрани, які дозволяють ознайомитися із розкладом, розташуванням аудиторій на поверсі, а також переглянути найсвіжіші новини університету. 
Сілезький університет в Катовіце є одним із найбільших закладів вищої освіти на території Польщі та у Верхній Сілезії.Університет славиться своєю величчю та незвичайною архітектурою будинків у яких розміщуються факультети. Так один 3 них отримав архітектурну премію авторитетного журналу Polityka, як найкраща споруда в Польщі. Заклад налічує близько 12 факультетів і на сьогодні у ньому навчається близько 35000 студентів. Серед них велику частку займають іноземні студенти. Враховуючи усі фактори можна стверджувати, що в Сілезькому університеті безумовно професійно налагоджена система управління. Але чи $\epsilon$ наявні відмінності із українським Національним університетом «Острозька академія» у застосуванні інформаційнокомунікаційного менеджменту?

Перш за все, потрібно розібратися 3 інформаційними процесами. На рисунку 2 зображено схему передачі інформації в університеті [10].

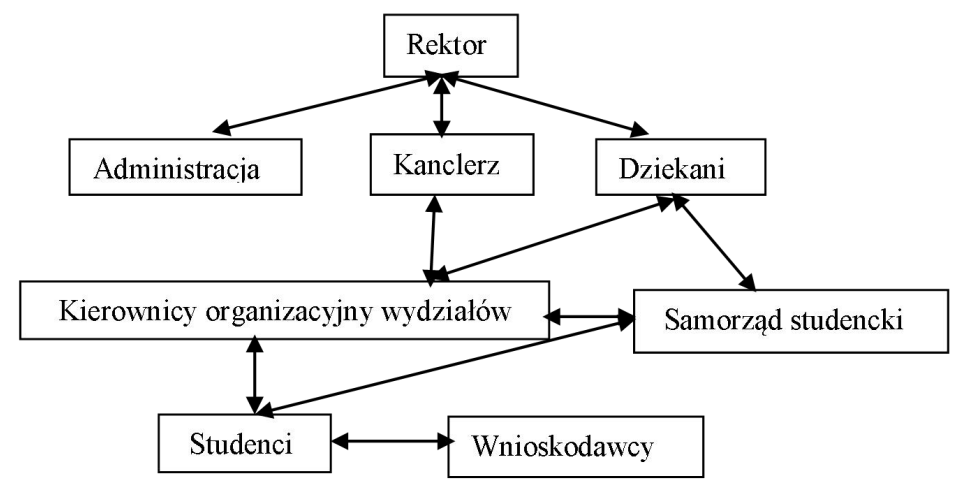

Рис. 2. Передача інформації у Сілезькому університеті

Інформаційно-комунікаційна сфера в університеті є налагодженою та чіткою.Для цього дослідження використано метод включеного спостереження, тому дані результати $є$ дійсними. Оскільки,завдяки перебуванню у Сілезькому університеті протягом навчального семеструбула надана можливість наочно ознайомитися зі всіма процесами глибше.3 представленого рисунку, можна зробити висновок, що інформування та комунікація у Сілезькому університеті має відкритий характер. Саме тому певні підрозділи займаються організацією власної життєдіяльності власноруч, незважаючи на інші керівні органи управління.

Основну ж роль в інформаційно-комунікаційному менеджменті відіграють методи, завдяки яким поширюють та збирають інформацію. У Сілезькому університеті використовують декілька способів, серед них: друковані носії, електронні носії та соціальні мережі.

Серед друкованих носіїв найчастіше у закладі вищої освіти можна зустріти роздрукований розклад, різноманітні афіші, буклети, листівки, подяки, графік роботи викладача та деканату. Це все розташовано на інформаційних стендах. 
Найпопулярнішим способом інформування та комунікації між професорськовикладацьким складом та студентами є система USOS (віртуальний деканат). Саме сюди керівник спеціальності надсилає усю потрібну інформацію групі. Ще одним способом є електронна пошта та Facebook.Студент має можливість ознайомитися iз основними новинами на офіційній сторінці університету, чи спільноти студентського самоврядування у Facebook.Саме у цій соціальній мережі студенти та викладачі Сілезького університету спілкуються між собою і допомагають у розв'язанні питань. Звісно ж не потрібно забувати про Instagram. У польському університеті він також поширений. $€$ головна сторінка університету, студентського самоврядування і певних факультетів, де публікують цікавий контент для студентів.

Електронні носії відіграють важливу роль у Сілезькому університеті. У вищому навчальному закладі, розповсюдженим засобом передавання інформації для студентів $\epsilon$ телевізор. Що стосується зборів університету, факультету, старостатів, то вони не популяризовані.Адже університет зосереджується на е-врядуванні. Для створення дружньої атмосфери серед студентів проводиться щорічний фестиваль - Juwenalia. Разом 3 цим студентське самоврядування проводить різноманітні заходи для студентства та викладачів.

Висновок. На даний момент інформаційно-комунікаційний менеджмент займає важливе місце у роботі університетів та організацій. Оскільки, запорука успіху полягає у правильному забезпеченні здійснення усіх видів менеджменту. Без інформації та комунікації він попросту є неможливим. В той час, коли розвиток інформаційнокомунікаційних технологій створює набагато ефективніші умови для роботи та задає правильний робочий ритм в освітніх установах. На прикладах Національного університету «Острозька академія» та Сілезького університету в Катовіце досліджено та оцінено роль налагодженої роботи інформаційно-комунікаційного менеджменту в університетах та створено рекомендації для них.

У ході дослідження Національний університет «Острозька академія» продемонстрував чудові результати. Відкритий характер комунікації між студентством та професорськовикладацьким складом. Інформування відбувається на всіх рівнях однаково і $\epsilon$ взаємопов'язаним. Методи поширення інформації та спілкування є дуже розвиненими. Оскільки, всю потрібну інформацію можна знайти у різноманітних видах: електронну, друковану, усну та телевізійну. Великим плюсом є те, що університет проводить велику роботу по внутрішній комунікації. Зустріч із ректором, зустрічі факультетів, старостати дають змогу висловити свою думку, поділитися проблемою або ж надати рекомендації щодо іiі вирішення. Завдяки таким способам студенти відчувають підтримку. Також невід'ємну роль відіграє створення офіційних сторінок університету та факультетів у всіх соціальних мережах. Це не лише впливає на покращене інформування студентства, а на створення позитивної репутації у зовнішньому середовищі, а також можливість абітурієнтів чи іноземних студентів дізнатися більше нового про Національний університет «Острозька академія». Що ж стосується рекомендацій для українського вищого навчального закладу. Потрібно продовжувати підтримувати ефективне 
спілкування та інформування усіх підрозділів університету, а також урізноманітнювати комунікацію між професорсько-викладацьким складом та студентами.

У Сілезькому університеті ситуація 3 інформаційно-комунікаційним менеджментом дещо відрізняється від українського університету. Звісно ж відкритий характер має інформування та комунікація, але певні підрозділи $\epsilon$ незалежними у своїй діяльності, тому інформаційні процеси не завжди є цілісними та взаємопов'язаними. Під час дослідження вдалося ознайомитися 3 найпопулярнішими способами комунікації та інформування. Серед них велику частку займає електронне спілкування. Для чіткої роботи створено віртуальний деканат, де студент може отримати всю потрібну інформацію про заняття, університетське життя та отримати коментарі, які стосуються його наукової роботи. У польському університеті студентське самоврядування проводить заходи, які допомагають створити не тільки дружню атмосферу, а й покращити загальну обізнаність студентів. Щодо рекомендацій для польського закладу вищої освіти, то потрібно підтримувати інформаційно-комунікаційну систему, яка $є$ впровадженою в університеті, адже це продовжуватиме покращувати атмосферу та спровокує зміцнення відносин між всіма факультетами та професорсько-викладацьким складом.

\section{References}

1.Bebyk V. M. Informacijno-komunikacijnyj menedzhment u hlobal"nomu suspil"stvi [Elektronnyj resurs] / V. M. Bebyk - Rezhym dostupu do resursu: https://studentbooks.com.ua/content/view/1030/42/1/1/.

2.Vnutrishni komunikaciyi: najkrashhi praktyky [Elektronnyj resurs]. - 2019. - Rezhym dostupu do resursu: http://open.kmbs.ua/internal-communications-best-practices/.

3.Zacerkivna M. O. PR-texnolohiyi u formuvanni imidzhu zakladiv vyshhoyi osvity sfery kul"tury: dys. kand. nauk z soc. komun. : 27 / Zacerkivna Maryna Oleksiyivna - Kyyiv, 2019. - 244 s.

4.Komunikaciyi v orhanizaciyax: proces, typy, zv'yazky, bar'yery. [Elektronnyj resurs]. - 2011. - Rezhym dostupu do resursu: https://osvita.ua/vnz/reports/management/15040/.

5.Nacional"nyj universytet «Ostroz"ka akademiya» [Elektronnyj resurs] - Rezhym dostupu do resursu: https://www.oa.edu.ua/.

6.Matviyenko O. V. Osnovy informacijnoho menedzhmentu [Elektronnyj resurs] / O. V. Matviyenko. - 2016. Rezhym dostupu do resursu: https://studfile.net/preview/5043453/page:3/.

7.Chernysh O. V. Stratehichne upravlinnya osvitn"oyu diyal"nistyu u ZVO [Elektronnyj resurs] / O. V. Chernysh. - 2018. - Rezhym dostupu do resursu: http://www.economyandsociety.in.ua/journal/19_ukr/107.pdf.

8.Herget I. Konzeption des Infornations managements in Informations wissen schaftlichen Studien angeboten / I. Herget ; Informations spezialisten fur Europa. - Proceedings : Konstanz, 1990.- 534 r.

9.Malara Z. Zarządzanie informacją na rynku globalnym [Elektronnyj resurs] / Z. Malara, J. Rzęchowski. 2011. - Rezhym dostupu do resursu: https://pdf.helion.pl/e_0ez9/e_0ez9.pdf.

10.Uniwersytet Śląski w Katowicach [Elektronnyj resurs] - Rezhym dostupu do resursu: https://us.edu.pl/. 


\section{СПИСОК ВИКОРИСТАНИХ ДЖЕРЕЛ ТА ЛІТЕРАТУРИ}

1. Бебик В. М. Інформаційно-комунікаційний менеджмент у глобальному суспільстві [Електронний pecypc] / В. М. Бебик - Режим доступу до ресурсу: https://studentbooks.com.ua/content/view/1030/42/1/1/.

2. Внутрішні комунікації: найкращі практики [Електронний ресурс]. - 2019. - Режим доступу до pecypcy: http://open.kmbs.ua/internal-communications-best-practices/.

3. Зацерківна M. O. PR-технології у формуванні іміджу закладів вищої освіти сфери культури: дис. канд. наук з соц. комун. : 27 / Зацерківна Марина Олексіївна - Київ, 2019. - 244 с.

4. Комунікації в організаціях: процес, типи, зв'язки, бар'єри. [Електронний ресурс]. - 2011. - Режим доступу до ресурсу: https://osvita.ua/vnz/reports/management/15040/.

5. Національний університет «Острозька академія» [Електронний ресурс] - Режим доступу до pecypcy: https://www.oa.edu.ua/.

6. Матвієнко О. В. Основи інформаційного менеджменту [Електронний ресурс] / О. В. Матвієнко. 2016. - Режим доступу до ресурсу: https://studfile.net/preview/5043453/page:3/.

7. Черниш О. В. Стратегічне управління освітньою діяльністю у ЗВО [Електронний ресурс] / О. В. Черниш. - 2018. - Режим доступу до ресурсу: http://www.economyandsociety.in.ua/journal/19 ukr/107.pdf.

8. Herget I. Konzeption des Infornations managements in Informations wissen schaftlichen Studien angeboten / I. Herget ; Informations spezialisten fur Europa. - Proceedings : Konstanz, 1990.- 534 p.

9. Malara Z. Zarządzanie informacją na rynku globalnym [Електронний ресурс] / Z. Malara, J. Rzęchowski. - 2011. - Режим доступу до pecypcy: https://pdf.helion.pl/e_0ez9/e_0ez9.pdf.

10. Uniwersytet Śląski w Katowicach [Електронний ресурс] - Режим доступу до ресурсу: https://us.edu.pl/. 